\title{
Estimation of the Harrod-Domar Growth Equation: Pakistan's Case
}

\author{
Sumair Siraj and Kaiser Bengali \\ SZABIST \\ Karachi, Pakistan
}

\begin{abstract}
The Harrod-Domar growth model is an economic model that purports to explain the economic growth process by establishing a relationship between an economy's saving rate, capital-output ratio, and GDP / GNP (national income) growth rate. Estimating the Harrod-Domar equation, using Pakistan's data, would establish whether the model is relevant to Pakistan, and whether the model satisfactorily explains Pakistan's economic growth. Since savings form an important part of the equation, estimating the savings function to identify its determinants would also prove beneficial. The savings function estimation would explain whether higher income levels and interest rates mobilize more savings in Pakistan.
\end{abstract}

Keywords: Harrod-Domar Growth Model, Savings, Investment, Capital-Output Ratio, Pakistan

\section{HARROD-DOMAR GROWTH MODEL}

The Harrod-Domar growth model [1] is an economic model that purports to explain the economic growth or economic development process by establishing a relationship between an economy's saving rate, capital-output ratio 1 , and the GDP / GNP ${ }^{2}$ (national income) growth rate. Mathematically, the Harrod-Domar equation can be stated as:

$$
\Delta Y / Y=s / \boldsymbol{k}
$$

Where,

$\begin{array}{lll}\Delta Y & \rightarrow & \text { Change in GDP / GNP } \\ Y & \rightarrow & \text { GDP / GNP in preceding year } \\ s & \rightarrow & \text { National savings rate } \\ k & \rightarrow & \text { National capital-output ratio }\end{array}$

The above-mentioned equation is derived as follows ${ }^{3}$ :

$$
S \quad=\quad I
$$

Where ' $\mathrm{S}$ ' represents national savings, and ' $\mathrm{I}$ ' represents investment. ' $S$ ' is derived through the product of savings rate (denoted by ' $\mathrm{s}$ ') and national income (denoted by ' $\mathrm{Y}$ ').

$$
I \quad=\Delta K
$$

\footnotetext{
${ }^{1}$ Also called the incremental capital-output ratio (ICOR)

${ }^{2}$ Gross domestic product / gross national product

${ }^{3}$ See [2]

Journal of Independent Studies and Research (JISR)

Volume 5, Number2, July 2007
}

Where ' $\mathrm{I}$ ' is investment (as above), and ' $\mathrm{K}$ ' represents change in capital stock or capital accumulation. ' $\Delta \mathrm{K}$ ' is derived through the product of capital-output ratio (denoted by ' $\mathrm{k}$ '), and change in national income (denoted by ' $\Delta \mathrm{Y}^{\prime}$ ').

Using equations (1) and (2), we get equation (3) given below.

$S \quad=\quad \Delta K$

Replacing equation (3) with its components, we get equation (4) given below.

$s Y \quad=\quad k \Delta Y$

Cross-multiplication of the two sides results in equation (5) given below.

$$
s / k=\Delta Y / Y
$$

Equation (5) establishes a directly proportional relationship between an economy's savings rate and economic growth; and an inverse relationship between the capital-output ratio and economic growth.

The Harrod-Domar model assumes that all savings are converted into investment on a one-to-one basis, which in turn results in capital accumulation i.e. asset creation. This incremental capital enables an economy to produce more output, generate more income, hence, boost economic growth.

Although the Harrod-Domar equation identifies pivotal variables that influence economic growth, it is not exhaustive i.e. it cannot be inferred that the mere presence of these variables would result in economies growing in size. Reference [2] writes in his textbook that "the basic reason why the investment-led takeoff didn't work was not because more saving and investment isn't a necessary condition - it is - but rather because it is not a sufficient condition."4

This implies that economic growth cannot be achieved merely by mobilizing savings and maintaining an acceptable capital-output ratio, but by adequate and diligent utilization of these resources.

Applying this model to Pakistan' economy would be useful in verifying the Harrod-Domar model and in 
determining whether Pakistan's economic growth has been a function of the two variables identified by Harrod and Domar, i.e. is Pakistan's GDP growth rate = $f$ (national savings rate, capital-output ratio).

It is important to understand that the purpose of this study is not to determine whether the GDP growth rate equates with the division of savings rate to capitaloutput ratio (i.e. is GDP growth equal to $\mathrm{s} / \mathrm{k}$ or not). The objective of this paper is to determine whether changes in savings and capital-output ratio significantly explain changes in national income / GDP.

Since 'savings' is the starting point, and an important variable in the analysis, the study also tries to gauge the impact of income level and interest rates on the national savings rate. The study would attempt to answer the following questions:

a. Does the Harrod-Domar model satisfactorily explain Pakistan's economic growth (historically and recently)?

b. Have higher income levels and higher interest rates mobilized greater savings in Pakistan?

The paper is structured as follows: Section 2 presents a brief literature review of the Harrod-Domar growth model and savings. Section 3 discusses the development models that have followed the model in question. The research methodology has been discussed in Section 4. Section 5 presents the data and its sources. Section 6 comprises of data analysis and results. Section 7 concludes the paper.

\section{LITERATURE REVIEW}

Although the model was developed in the 1940s, and number of economic development models that are much more comprehensive have developed since then, it seems that the popularity of the Harrod-Domar equation has not faded away. Reference [3] points out that economists "still apply the Harrod-Domar growth model to calculate short-run investment requirements for a target growth rate." International donor agencies, including the Word Bank, continue to use the product of target growth rate and incremental capital-output ratio (ICOR) to calculate a country's investment requirements. The gap between the required investment and the actual national savings is then financed through foreign aid. [3].

The widespread application of the model can be attributed to its simplicity. The proponents of the model believe that even the most complex economic development models use the Harrod-Domar equation as their fundamental base. They might also argue that since the models that followed Harrod-Domar do not exclude the variables identified by the equation as insignificant, the equation can safely be used to ascertain a country's economic growth.
The critics of the model, however, feel that the equation is too simple to use. Moreover, it ignores other variables that have been shown to have a considerable impact on economic growth. Reference [3] writes that Evsey Domar, himself, admitted that the assumption about the proportionality of capital stock and productive capacity, which he had made in his paper "Capital Expansion, Rate of Growth, and Employment" [1], was unrealistic.

Another argument against the Harrod-Domar model, and probably the most convincing one yet, is that it ignores the impact of technological progress on economic growth; a variable introduced by [4] is his neoclassical growth model, which is in fact an extension of the Harrod-Domar model. Reference [5]'s estimation results show that growth in output and capital are correlated with technological change. Mathematically, the Solow model can be written as:

$\mathrm{Y}=\mathrm{AK}^{\alpha} \mathrm{L}^{1-\alpha}$

Where,

$\begin{array}{llll}\mathrm{K} & \rightarrow & \text { Capital input } & \\ \mathrm{L} & \rightarrow & \text { Labor input } & \\ \alpha & \rightarrow & \text { output elasticity } & \\ \mathrm{A} & \rightarrow & \text { Solow residual, which } & \text { represents } \\ & \text { technology or technological } \\ & \text { progress } & \end{array}$

Equation 6 shows that keeping inputs ' $\mathrm{K}$ ' and ' $\mathrm{L}$ ' constant, an increase in 'A' will result ' $Y$ ' (total output) increasing, which means that short-run economic growth can be achieved without increasing capital.

Despite these criticisms, the Harrod-Domar model continues to be a basis for other growth models, and the international community continues to apply the HarrodDomar equation to forecast economic growth figures. The World Bank uses the Revised Minimum Standard Model (RMSM), a computerized version of the HarrodDomar model that was developed by John Holsen in 1971, and named the Minimum Standard Model [3] $]^{6}$.

Since the paper also deals with estimating the savings function, a brief mention of the savings trend in Pakistan will be beneficial to our work. The average national, domestic, and private savings rate in Pakistan

\footnotetext{
${ }^{5}$ The symbol ' $\mathrm{A}$ ' is also referred to as total factor productivity (TFP) in economic literature.

${ }^{6}$ The Minimum Standard Model (MSM) was developed by World Bank economist, John Holsen in 1971. The model was later revised by Nicholas Carter and Norman Hicks, and renamed the Revised Minimum Standard Model (RMSM). An extended version of the model, called RMSM-X was created in 1990.
} 
is estimated to be $15.6 \%, 12 \%$, and $14 \%$ respectively $^{7}$ from FY'73 to FY'03. The national savings rate has gradually increased from $8.5 \%$ in $1972-73$ to $26.8 \%$ in 2002-03. Reference $[6]^{8}$ has put the average domestic saving rate in Pakistan at around $12 \%$ for the last four decades. The sectoral break-down of savings in [6] shows that private savings account for over $90 \%$ of national savings in Pakistan.

Since the Harrod-Domar model considers savings to be a major determinant of economic growth, identifying the main determinants of savings would facilitate the development of policies that encourage savings. The determinants identified in the literature are per-capita incomes, real interest rates, taxes, financial liberalization, and financial deepening (i.e. availability of a wide range of savings instruments).

Reference [7] asserts that studies on savings in India have yielded the following results:

1. Rising per-capita incomes have a "weak positive effect on private saving."

2. Financial deepening, measured by the moneyto-GDP ratio has increased saving.

3. Real interest rates have a directly proportional relationship with savings.

With regards to savings-income relationship, "at very low levels of income per capita, the total savings is close to zero" and "as income increases, savings rates rise at a faster rate than that of the income." [8]

Reference [9] is also of the view that countries with a "deeper" financial system tend to have higher private saving rates, and that the money-to-GDP ratio coefficient (representative of financial deepening) always comes out significant.

Recent findings suggest that private saving rates fail to rise with higher interest rates and tax incentives $[7]^{9}$. With regards to saving-interest relationship in Pakistan, however, "there is a strong positive relationship between saving and real interest rates." [6]

\section{HARROD-DOMAR MODEL: AN OVERVIEW OF SUCCESSORS}

Since the Harrod-Domar model did not account for other important variables that could impact economic growth, the equation was overtaken by the structural change models. The structural change models attributed

\footnotetext{
${ }^{7}$ National and domestic saving rates are defined as the ratios of national savings and domestic savings to gross domestic product respectively.

${ }^{9}$ Cited by [7] from Engen et al., 1994; OECD, 1994

Journal of Independent Studies and Research (JISR) Volume 5, Number2, July 2007
}

economic growth to structural transformations within an economy that resulted in the reallocation of economic resources from traditional to modern sectors.

The most well-known of the structural change models is the Lewis' two-sector model ${ }^{10}$, which focused on the mechanism of transformation from a subsistence economy to an industrialized one. The model argued that the transfer of rural surplus labor to the urban sector would increase industrial output without any loss in agricultural output. ${ }^{11}$ The transfer, therefore, would result in the overall economy growing $[10]^{12}$.

Eventually, the Lewis model also lost its ground as it failed to explain actual economic developments and underdevelopments of the time. Also, the model's assumptions were considered to be unrealistic. For instance, assumptions that all capital profits would be reinvested, and that rate of labor transfer is proportional to rate of capital accumulation did not prove to be valid.

The structural change models were followed by international dependence models that offered qualitative explanations for economic growth. They argued that underdevelopment was a result of an exploitative capitalist system that concentrated on maintaining a dependence-dominance relationship (where poor, underdeveloped economies were the dependent parties, while the rich, developed economies were the dominant counterparts). They proposed that a revolution to disrupt the dependent-dominant relationship would enable stimulate economic growth in poor economies [2].

The neoclassical counterrevolution followed the dependence revolution models, and they cited government failure as the main reason for low economic growth rates. They believed that trade and financial liberalization, privatization, and government non-intervention in the market mechanism would promote economic growth. The current IMF-WTO backed neo-liberal economic policies have their roots in the neoclassical counterrevolution theories.

\section{RESEARCH METHODOLOGY}

The research methodology entailed estimating the Harrod-Domar growth equation through regression analysis $^{13}$, using the ordinary least square (OLS)

\footnotetext{
${ }^{10}$ The Lewis two-sector model was developed by [10]. The model was later modified by John Fei and Gustav Ranis [3].

${ }^{11}$ Zero marginal labor productivity assumption

${ }^{12}$ Cited by [2]; p. 84-89

${ }^{13}$ Regression analysis is concerned with the study of the dependence of one variable, the dependent variable, on one or more other variables, the explanatory variables, with a view to estimating and/or predicting the (population) mean or average value of the former in terms of the known or fixed (in repeated sampling) values of the latter.
} 
method. Since savings is a determinant of growth, the savings function has also been estimated. The equations that are estimated are as follows:

$$
\begin{aligned}
& \mathrm{Y}=\mathrm{f} \text { ( savings rate, capital-output ratio) } \\
& \mathrm{S}=\mathrm{f}(\text { per capita income, interest rate) }
\end{aligned}
$$

Where ' $\mathrm{Y}$ ' is national income and ' $\mathrm{S}$ ' is savings; Savings rate, capital-output ratio, per capita income, and interest rate are explanatory variables that are used to estimate or predict the dependent variables, national income and savings respectively.

\section{DATA AND SOURCES ${ }^{14}$}

The data that is required to estimate the HarrodDomar equation and the savings functions comprises of GDP, savings, capital-out-put ratio, per-capita income, and average deposit rate figures. Data for GDP, savings, per-capita income, and deposit rate is available from secondary sources. Computation of the capital-output ratio (ICOR) has been discussed in the next section.

Gross domestic product and gross fixed capital formation have exhibited an increasing trend in the last 30 years, suggesting that asset accumulation seems to have led to increases in output. It is interesting to note that national and domestic savings have not responded to interest rates as expected, in Pakistan historically. A dramatic jump in average deposit rates from $5.97 \%$ in FY' 85 to $8.98 \%$ in FY' 86 , resulted in domestic savings showing a subtle increase from PKR 46, 262 million to PKR 56, 193 million during the same period. That is, a $50.4 \%$ increase in interest rates lead to a much lower $21 \%$ increase in domestic savings. Furthermore, declining rates from FY'97 onwards actually caused both domestic and national savings to increase drastically (see Figure 3). This might suggest a weak link between interest rates and savings in Pakistan.

The diagrams show the trends of the selected variables in the last 30 fiscal years.

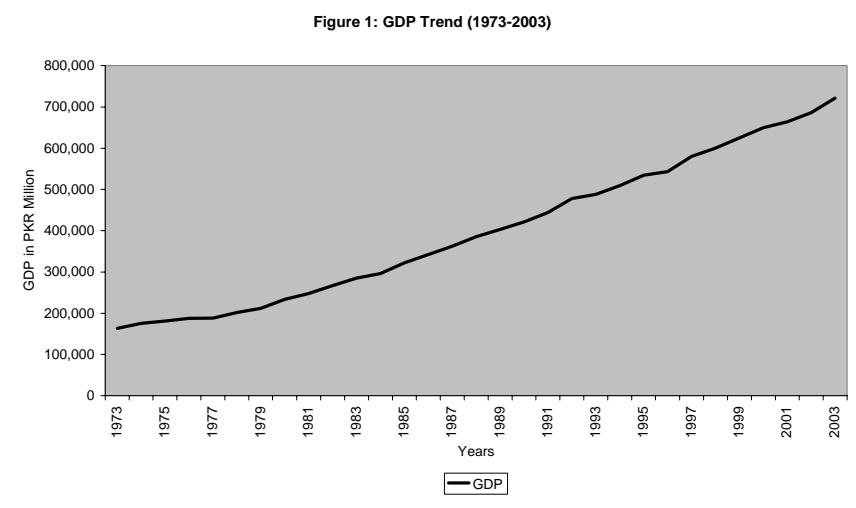

\footnotetext{
${ }^{14}$ The source of all figures is [11] and [12].

Journal of Independent Studies and Research (JISR)

Volume 5, Number2, July 2007
}
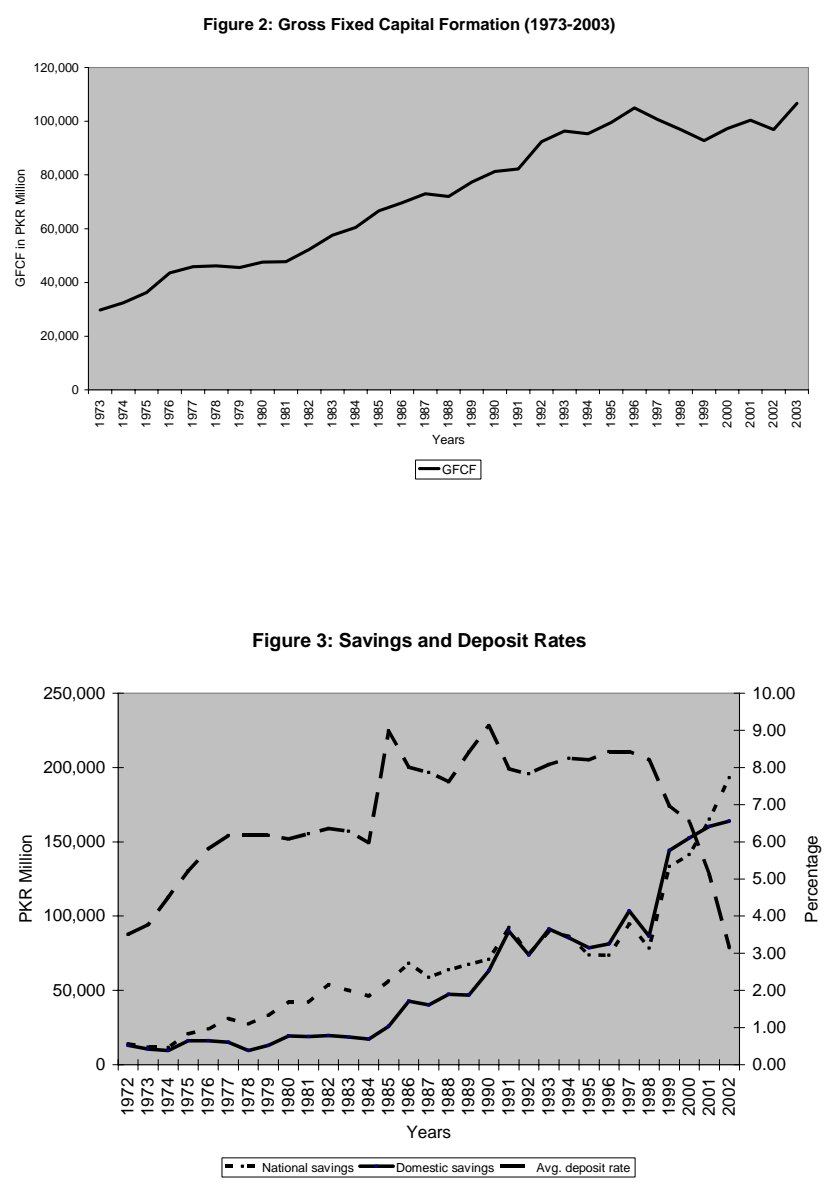

\section{DATA ANALYSIS AND ESTIMATION RESULTS}

The analysis covers a period of 30 fiscal years, from the year 1972-73 (FY'73) to the year 2002-03 (FY'03). Regarding the estimation of the HarrodDomar equation, values of all selected variables are in constant prices of 1980-81 (FY'81). We decided to use the year 1980-81 as the base year because of its consistency. Bases were revised in the year 1999-2000, but we decided not to use them as we felt they would not be an appropriate representative of past figures.

Natural $\operatorname{logs}^{15}$ of real GDP, national savings, capital-output ratio, per-capita income, and average deposit rate figures have been used for the estimations. National savings figures were available at current prices i.e. they had different bases. The figures were transformed into constant prices by dividing the current figures with the respective GDP deflators (with the 1980-81 base). GDP deflator figures were also not available for pre-1981 and post 2000 periods. Splicing technique was used extrapolate these numbers with a

\footnotetext{
${ }^{15}$ A logarithm is the power to which a base must be raised in order to get a certain number. Natural logs have a base of $\mathrm{e}=2.718$, while common logs have a base of 10 .
} 
base of 1980-81. Capital-output ratios have been calculated by applying the standard formula i.e. dividing changes in capital stock by changes in GDP, and inversing the result. Gross fixed capital formation values were used to compute capital stock.

Regarding the estimation of the savings function, again all figures are in real terms, with $1980-81$ as the base year, and have been converted into natural logs. Per capita income and average deposit rate figures were used as explanatory variables. The diagrams below show the trends of the selected variables in the last 30 years.

The regression results are as follows:

With regard to the Harrod-Domar equation, where $\log$ of GDP are regressed with logs of national savings and capital-output ratio, we established the following equation:

$\mathrm{LGDP}=\mathrm{f}(\mathrm{LNATSAV}, \mathrm{LICOR})$

The results obtained area as follows:

\section{TABLE 1: Harrod-Domar Equation Regressions}

\begin{tabular}{lll}
$\begin{array}{ll}1973 \text { to } 2003 \\
0.497 \mathrm{NS}+0.910 \mathrm{k}\end{array}$ & $\mathrm{Y}=$ & $5.862+$ \\
$\mathrm{d}=0.505$ & $\mathrm{R}^{2}=0.922$ & $\mathrm{~F}=158.6$ \\
$\begin{array}{l}1978 \text { to } 2003 \\
0.039 \text { NSR }-2.649 \mathrm{ICOR}\end{array}$ & $\mathrm{PCH}=$ & $0.894+$ \\
$\mathrm{d}=1.943$ & $\mathrm{R}^{2}=0.401$ & $\mathrm{~F}=4.347$ \\
\hline
\end{tabular}

The estimated equation for the first regression equations that is obtained can be written as follows:

$$
\begin{aligned}
& \mathrm{Y} \\
& \mathrm{ICOR}
\end{aligned}
$$

Where 5.862 represents the constant term, 0.497 represents the coefficient for national savings, and 0.910 represents the coefficient for capital-output ratio

The $\mathrm{R}^{2}$ ( $\mathrm{R}$ square) ${ }^{16}$ is 0.922 , which means that the two selected independent variables explain $92.2 \%$ of the variation in the dependent variable. The adjusted $R^{2}$ is $0.916(91.6 \%)$.

The t-statistics ${ }^{17}$ for the constant term, national savings, and capital-output variables are +14.850 , +9.740 , and +3.562 .

\footnotetext{
${ }^{16}$ Coefficient of determination

${ }^{17}$ The t-test is a measure of the significance of individual variables in an estimated regression.
}

Journal of Independent Studies and Research (JISR) Volume 5, Number2, July 2007
The F-statistic ${ }^{18}$ and the Durbin-Watson statistic ${ }^{19}$ are 158.6 and 0.505 respectively.

The estimated results have the following problems, however, which rendered the equations unusable.

The capital-output ratio coefficient came out to be positive $(+0.910)$, which is not consistent with economic theory. ICOR and GDP have an inverse relationship, and therefore, the sign of the coefficient should be negative. The D-W statistic is also problematic.

Since the estimated regression equations came out to be incorrect, and did not conform to economic theory, we ran a revised equation, the details of which are as follows.

The equation that is established to re-estimate the Harrod-Domar equation is:

\section{$\mathrm{LPCH}=\mathrm{f}(\mathrm{LNSR}, \mathrm{LICOR})$}

Where LPCH, LNS, and LICOR represent logs of per-capita GDP growth rate, national savings growth rate, and capital-output ratio. The number of observations for this regression has been reduced from 31 to 26 i.e. FY' 78 to $\mathrm{FY}^{\prime} 03$ data is used instead of FY'73 to FY'03.

Before discussing why the initial 5-year period 1973-77 was dropped, it is important to clarify the following point. Regression will work well if an economy has a stable economic structure. The explanatory power of a regression equation depends on variations in variables that are induced by variations in economic factors.

When an economic structure is unstable, or when are structural changes, then changes in the behavior of dependent variables are not correlated to one or more independent variables. In that case, a dummy variable can be introduced to explain the effect of this shock. However, such extensions are beyond the limited scope of our work.

Based on this understanding, we will now discuss why the 5-year period (from FY'73 -FY'77) was dropped. Pakistan's economy experienced significant structural changes after the separation of East Pakistan (now Bangladesh) in 1971. Trends in all economic variables ruptured, and the economic system faced a severe economic shock. The economic policies of the

\footnotetext{
${ }^{18}$ The F-test is a measure of the overall significance of the estimated regression. The F-test is also a test for determining the significance of $\mathrm{R}^{2}$.

${ }^{19}$ The Durbin-Watson test is a test for detecting serial correlation (correlation in time-series analysis).
} 
post-1971 also introduced a series of shocks in the form of large-scale public investments, which had long gestation periods. Although investment rates were high post-1971, the long gestation period of those investments caused GDP growth rates during that period to be very low.

While the Harrod-Domar model assumes that a change in capital (a result of investment) would lead to an immediate change in income (GDP), in this case, a change in capital could not lead to an immediate change in GDP, because of the long-gestation nature of investment. In fact, gains in income (due to investments) were achieved in the late1980s. So the normal relationship between the variation in capital, and variation in GDP during the 1973-77 period does not hold, rendering the ICOR problematic and, therefore, unusable. This is the reason why the 1973-77 period has not been considered in the estimation.

The revised regression equation provides the following results:

$\mathrm{PCH}=0.894+0.039 \mathrm{NSR}-2.649 \mathrm{ICOR}$

Where +0.894 represents the constant term, +0.039 represents the coefficient for national savings rate, and -2.649 represents the coefficient for ICOR.

The $\mathrm{R}^{2}$ is 0.401 , while the adjusted $\mathrm{R}^{2}$ is 0.308 . The t-statistics for the constant term, NSR, and ICOR are $+0.569,+0.359$, and -2.946 respectively. The F-statistic is 4.347, while the Durbin-Watson statistic is 1.943.

The result upholds the expected relationships i.e. the signs of the independent variables are correct. However, the results also show that the Harrod-Domar equation is under-specified i.e. the $\mathrm{R}^{2}$ is low at 0.401 , which is to be expected, as it does not take other variables into account, such as technology, human development, etc. The results also show that national savings is an insignificant explanatory variable ( $\mathrm{t}$ statistic $=0.359$ ).

With regard to the savings function, where log of domestic saving is regressed with logs of per-capita income and average deposit rate, we established the following equation:

\section{LDOMSAV $=\mathrm{f}(\mathrm{LPCY}$, LAVDRATE $)$}

The results obtained are as follows:

\section{TABLE 2: Savings Function Regressions}

$\begin{array}{lll}1973 \text { to } 2003 & \mathrm{~S}= & -22.495+ \\ 4.125 \mathrm{PCY}-0.345 \mathrm{ADR} & & \mathrm{F}= \\ 188.553 \mathrm{~d}=1.052 & \mathrm{R}^{2}=0.931 & \end{array}$

$\begin{array}{llll}1973 \text { to } 1998 & \text { PS } & -5.426 \\ 0.925 \mathrm{ADR}+1.758 \mathrm{PCY} & & & \\ & \mathrm{R}^{2}=0.937 & \mathrm{~F}\end{array}=$

The estimated equation for the first regression that was obtained can be written as follows:

$$
\begin{aligned}
& \mathrm{S}=-22.495+4.125 \mathrm{PCY}-0.345 \\
& \text { AVDRATE (11) }
\end{aligned}
$$

Where -22.495 represents the constant term, 4.125 represents the coefficient for per-capita income, and 0.345 represents the coefficient for average deposit rate.

The $\mathrm{R}^{2}$ is 0.931 , which means that the two selected variables explain $93.1 \%$ of the variation in the dependent variable. The adjusted $\mathrm{R}^{2}$ is $0.926(92.6 \%)$.

The t-statistics for the constant term, per-capita income, and average deposit rate variables are -12.919 , +17.943 , and -1.815 respectively. Per-capita income comes out to be statistically significant, while average deposit rate is very close to being considered as significant, though it comes to be insignificant. The Fstatistic is 188.553 and the Durbin-Watson statistic is 1.052 .

The estimated results have the following problems, however, which rendered the equations unusable. The average deposit rate coefficient came out be negative (0.345), which means that rising interest rates cause savings to decline. The sign again is incorrect, and needs to be corrected.

Since the estimated regression equations came out to be incorrect, and did not conform to economic theory, we ran a revised equation, the details of which are as follows.

The equation that is established to re-estimate the savings function replaced domestic saving with private savings ${ }^{20}$, which is estimated as a function of average deposit rate, and per-capita income respectively. The number of observations for this regression has also been reduced from 31 to 26 i.e. FY' 73 to FY'98 data has been used instead of FY'73 to FY'03. ${ }^{21}$

The reason for doing this is because interest rates in the late 1990s exhibited abnormal behavior, which could be attributed to exogenous shocks. An example of an exogenous shock is the flow of remittances that increased after the 9/11 attacks, which caused savings

\footnotetext{
${ }^{20}$ Private savings account for a major portion of national savings (see p. 8)

${ }^{21}$ Data from FY'99 to FY'02 was dropped.
} 
rates to rise, despite declining interest rates. Remittances increased by $119.9 \%$ from $\$ 1,086.57$ million in FY'01 to $\$ 2,389.05$ million in FY2005. ${ }^{22}$

The estimated equation that was obtained can be written as follows:

PS

$$
=\quad-5.426+0.925 \mathrm{ADR}+1.758 \mathrm{PCY}
$$

Where -5.426 represents the constant term, +0.925 represents the coefficient for average deposit rate, and +1.758 represents the coefficient for per-capita income.

The $\mathrm{R}^{2}$ is 0.937 . The t-statistics for the constant term, ADR, and PCY are $-2.723,+3.864$, and +6.027 respectively. The F-statistic is 170.746 , while the Durbin-Watson statistic is 1.664

The results show that the established savings function is relevant to Pakistan, as the $\mathrm{R}^{2}$ shows that the two selected explanatory variables significantly explain the dependent variable, and all t-statistics are significant.

\section{CONCLUSIONS}

In the light of data-analysis and estimated regression results, we can conclude the following:

1. National savings is a statistically insignificant explanatory variable for GDP (t-statistic = 0.359) in Pakistan.

2. The Harrod-Domar equation is under-specified $\left(\mathrm{R}^{2}=0.401\right)$, and does not fully explain variations in GDP.

3. Per-capita income and average deposit rates are statistically significant explanatory variables for private savings in Pakistan i.e. changes in per-capita income and interest rates significantly explain changes in private savings in Pakistan.

In conclusion, it can be confirmed that the HarrodDomar equation does not fully explain GDP growth in Pakistan, and cannot be applied in its simple form to estimate economic growth in Pakistan.

\section{REFERENCES}

[1] Domar, Evsey (1946); 'Capital, Expansion, Rate of Growth, and Employment'; Econometrica, Vol.14, p. $137-47$

[2] Todaro, Michael P. (2000); Economic Development $\left(7^{\text {th }}\right.$ edition $)$

${ }^{22}$ Reference [12]

Journal of Independent Studies and Research (JISR)

Volume 5, Number2, July 2007
[3] Easterly, William (1997); 'The Ghost of Financing Gap: How the Harrod-Domar Growth Model Still Haunts Development Economics'; Policy research Working Paper \# 1807, The World Bank Development Research Group

[4] Solow, Robert (1956); 'A Contribution to the Theory of Economic Growth'; Quarterly Journal of Economics, p. 65-94

[5] Romer, Paul M. (1989); 'What Determines the Rate of Growth and technological Change?'; WPS 279, Country Economics Department, The World Bank

[6] Vincelette, Gallina A. (2006); 'Determinants of Saving in Pakistan'; Report No. SASPR-10, SASPR Working Paper Series, World Bank

[7] Mühleisen, Martin (1997); 'Improving India's Saving Performance'; IMF Working Paper No. WP/97/4, International Monetary Fund, Asia and Pacific Department

[8] Akhtar, Sajjad (1979); 'Savings-Income Relationships in Urban Pakistan: Evidence from HIES 1979'; Pakistan Journal of Applied Economics (1986), Vol. V No. 1, (13--46)

[9] Edwards, Sebastian (1996); 'Why are Latin America's Savings Rates so Low? An International Comparative Analysis"; Journal of Development Economics Vol. 51, p. 5 -- 44.

[10] Lewis, Arthur W (1954); 'Economic Development With Unlimited Supplies of Labor'; Manchester School of Economics and Social Studies 22 (1954); p.139--191

[11]Economic Surveys of Pakistan; Editions 1985-86, 2001-02, 2002-03, 2005-06.

[12] State Bank of Pakistan; Hand Book of Statistics on Pakistan's Economy (2005) 